\title{
The Roman Catholic Liturgy and Its Role in the Composer's Missa Formation
}

\author{
Olena Roshchenko*, Nataliya Byelik-Zolotaryova**
}

\begin{abstract}
A number of interdependent problems was solved in this study: the missa concept meanings' system definition in the context of the Roman Catholic liturgy; the order of the missa's musical sections in the liturgy's structure; the invariant-variant nature of the Gregorian Masses; the theological and musical preconditions for the composer's mass genesis. The purpose of the study is the liturgical context of the composer's mass determination as a musical genre and a subject for a musicological analysis. It is stated that missa's range of meanings extends from the word to the liturgy analogue and from the sequence of musical and verbal parts, divided by the rite actions, to the antiphonary where they are present without verbal sacred "insertions"; from the liturgy to the composer's genre as an entire cyclical artistic phenomenon of authorial origin. The Roman Catholic liturgy equal to the missa, and the missa as an extra-liturgical phenomenon of the composer's creativity have a different number of musical sections. In the Gregorian Mass, in the Antiphonary's composition as an obligatory component of the liturgy, the imitation of the canon presented in eighteen musical versions of sacred monophonic singing dominates. In the composer's missa, the distancing from the liturgical source has led to its free interpretation, as well as to the changes in its purpose, location, target audience, words and music interaction. It is the place of the missa's musical sections in the liturgical action that is determined here. While the church mass is not entirely musical, the composer's missa is based exclusively on a musical drama. The logic of a change from one section of the musical missa to the next is due to the development of the liturgical action. The cyclical nature as a principle of form and content formation is inherited by the composer's missa from the liturgical prototype.
\end{abstract}

Keywords: medieval liturgy, composer's missa, supragenre memory, ordinarium, antiphonary, mass, missio

\footnotetext{
* Olena Roshchenko , Habilitated Doctor of Art Criticism, Professor, Head of the Theory and History of Music Department, Kharkiv State Academy of Culture, Ukraine. e-mail: elena.roshenko@gmail.com (corresponding author).

ORCID ID: orcid.org/0000-0002-6048-6335.

** Nataliya Byelik-Zolotaryova, $\mathrm{PhD}$ in Arts, Professor of choral conducting, Kharkiv National Kotlyarevsky University of Arts, Ukraine

ORCID ID: orcid.org/0000-0003-3670-4037.
} 


\section{The missa concept meanings' system unity definition in the context of the Roman Catholic liturgy}

The etymological meaning of missa is derived from the Latin word "send, release", acquiring the meaning of "dimissio" (dismissal) ${ }^{1}$, which expresses the general unity of a matter and a purpose of the Roman Catholic liturgical action. Remaining the etymological unity, the meaningful volume of the missa in the context of liturgical action acquires a functional (multilevel) polysemy. These are absolution, forgiveness, sacrifice, the prayer for "Sending the Holy Spirit for the Holy Gifts Consecration", the benediction of the faithful people, the Eucharist as Thanksgiving. At different stages of the liturgy development there has been a change in the inherent structure for mass functions, the interaction of which forms a temple-sacred prayer action and corresponded to a single purpose in the following way: the objective of "missa" is to dismiss the "announced" from the temple (that is, the unbaptized), who are called to receive the Holy Sacrament of Baptism. The "announced", as well as those who repent, have the right to be present only at the "Liturgy of the Word" (the reading of God's Word - the Holy Scriptures - is its centre); after that they must leave the temple.

The coexistence of several interdependent meanings of the missa essence, which has different content and structural functions, is a characteristic feature. The missa's range of meanings extends from the word to the monumental volume of the whole liturgy analogue; from the sequence of musical and verbal parts, divided by the rite actions, to the antiphonary where they are present without verbal sacred "insertions"; from the liturgy to the composer's genre as an entire cyclical artistic phenomenon of authorial origin.

Missa as a word: a meaning amount. The word "missa" is proclaimed in the liturgy only once; it is present in the liturgy of the Eucharist in the Priest's final call: "Ite, Missa est" ("Go, you have been dismissed"). The word "missa" used at the end of the liturgy means the statement of purification, absolution of the congregation, which is the achievement of the sacred temple action's end. It is important to note that the only proclamation during the liturgy of the "missa" keyword is connected exactly with its musical use. Thus, the importance of the liturgy's musical component increases significantly.

Missa as the liturgy's analogue. In the Middle Ages missa appeared as an analogue of the liturgy, having no artistic significance, as well as the

\footnotetext{
${ }^{1}$ Simakova, Natalia, Vokal'nyye zhanry epokhi Vozrozhdeniya [Renaissance vocal genres], Muzyka, Moscow, 1985, p. 15.
} 
author's characteristic. It also appeared as a generalization of the majestic centuries-old Christian (sacred) pre-medieval experience, which had been perfected over the medium aevum millennium, reflecting the stages of Christian history, Christian doctrine development, showing significant changes in theology. Remaining canonical, medieval missa was not static.

Missa as a word or concept and missa as liturgy are directly interconnected. The multi-stage, expansive "missa", equal to the liturgy, takes place for the final proclamation of the parishioners' sins forgiveness. The missa's purpose as liturgy is realized by dismissal at the end of the sacred action.

Missa as an analogue of the liturgy's musical parts. "Missa" acquires in this context other shades of meaning as an expression of the liturgy's musical component. The sources of the missa's musical component interpretation's knowledge are contained in the sacred book "Liber Usualis Missae et Officii". Gregorian chants that accompany the liturgical action at an appropriate stage of its development are combined in 18 missae. Moreover, "Liber Usualis Missae et Officii" appears as a source of the scientific commentaries on the neume notation reading's specifics, its classification, rhythmics features, phrasing, as well as their choral performance features ${ }^{2}$.

An antiphonary's missae. The musical sections of the Roman Catholic liturgy are fragments of the church action's liturgy. However, acquiring the functions of solo-choral generalization and combination of liturgical and verbal stages of sacred action, as well as a prayer address to the Persons of the Holy Trinity, the Mass'musical sections contain the spiritual memory of the entire Church's prayer "doing". Unlike the liturgy, in which the musical parts do not follow one another, in the Church service there was a tradition of the Antiphonary forming, in which the six major musical sections of the Roman Catholic liturgy are written from "Kyrie" to "Ite, missa est".

The Antiphonary was of practical importance: it was intended for the Church choir, the precentor, as well as the priest and the congregation, whose voices join in the chanting of the liturgy's prayer fragments. Thus, the tradition of the Mass' integral musical interpretation has been established in the liturgy already, which should be considered as a precondition for the missa's emergence as a composer's (author's musical) work. The Gregorian Mass was a systemic prototype of musical semiotics.

Formed on the common construction principle, 18 missae "Liber Usualis Missae et Officii" appear in the Antiphonary's structure as prototypes of future composers' missae considered as works of art, which are transformed from the Latin liturgy's fragments into a musical-verbal cyclical integrity. Performing such a cyclical integrity acquires not so much a ritual but concert significance and requires a time-space change (the sacred Church

\footnotetext{
${ }^{2}$ Liber usualis missae et officii, Typis Societatis S. Joannis Evangelistae, Parisiis, Tornaci, Romae, 1953.
} 
chronotope is changed to the secular concert one). From the integration of originally anonymous musical parts of liturgical action, joined to the unified liturgy in different centuries of the Middle Ages, with the beginning of the composer's era in the European art the Mass had been gradually changed into an author's work of art of a cyclical nature. Exactly from this period missa exists in two cultural dimensions: as a liturgy and as a para-liturgical genre. Thus, the range of semantic polysemy, from the beginning inherent in the medieval missa, has been expanded.

\section{The order of the Mass' musical sections in the Roman Catholic liturgy's structure}

The Roman Catholic liturgy equal to the missa (Mass), and the missa as an extra-liturgical phenomenon of the composer's creativity, despite of the fact that it belongs to one liturgical source, have a different number of musical sections. In the Gregorian missa, in the Antiphonary's composition (which was made on the basis of six Gregorian chants) as an obligatory prayer component of the Roman Catholic liturgy (of a temple action), the imitation of the canon presented in eighteen musical versions of sacred monophonic singing dominates. In the composer's missa, the gradual distancing from the liturgical source has led to its more or less free interpretation. At the same time, the connection with the liturgical prototype is obligatory for the composer's missa.

The musical sections of the missa in the liturgy's composition are not a piece of art, nor a genre. The canon's dominance did not presuppose any manifestations of the individual, supplanted by theological doctrine as an objective Divine basis. Instead, in the composer's missa, under the conditions of its transformation into a musical genre, one can identiy the composer's interpretation of the canon, which presupposes a certain degree of freedom. Its purpose, location, performers, target audience, symbols, interaction of words and music are changed. If in the missa as a liturgy the word conquers its musical effects, then in the composer's missa the music is a dominant and content forming basis, which transforms the sacred word in its canonical meaning. As a result of the words and music combinations, there was a change of form in the missa: from the "textual-musical" in its temple source to the "musical-textual" in the early examples of the composer's missa, and then to the musical in its realizations, starting from the 18th century (according to Kholopova's opinion ${ }^{3}$ ). The Church missa is a rite, a temple action in which the music's purpose is to promote communion with the Lord through prayers. The musical sections in the missa do not have an independent meaning; they have an applied character as one of the means of

\footnotetext{
${ }^{3}$ Kholopova, Valentina, Formy muzykal'nykh proizvedeniy [Forms of Musical Works], Lan', St. Petersburg, 2001.
} 
carrying out the congregation's appeal to Heaven, to perform a sacred communication of the vertical type.

The missa as a composer's genre does not contain all the musical fragments inherent in the missa seen as liturgy. In the Roman Catholic liturgy, there are more musical parts than those usually associated with the missa's concert performance. We can identify the examples of introit, which is not a part of the traditional 5-section musical missa's cycle (bringing Requiem closer to a temple action Wolfgang Amadeus Mozart has included an introit into its structure), as well as the liturgy's final musical part ("Ite, Missa est"), in which the word "missa" is introduced only once during the church action.

The structure of the Holy (temple) missa as the liturgical action in the temple's time-space has remained unchanged for centuries. It consists of 4 parts: the initial rites, the liturgy of the Word, the liturgy of the Eucharist and the final rite. Those parts of the missa that are consistently arranged in the musical para-liturgical genre are contained in the church liturgy's different parts.

While the church missa is not entirely musical (in the church missa the reading of the sacred texts and symbolic action alternate with the musical parts), the composer's missa is based exclusively on a musical drama. The sections of the composer's missa reflect the liturgical context of the sacred action. The logic of a change from one section of the musical missa to the next in the primary sense is due to the development of the church liturgical action. Although in the composer's missa the broad liturgical context seems to remain outside its content, nevertheless an important task of the study is to reveal the semantic nature of the musical genre, due to the general liturgical course of the church action's development.

The cyclical nature of the genre of a sacred origin as a principle of form and content formation is one of the features inherited by the composer's missa from the liturgical prototype. The order of the sections of the composer's missa is inherited from the liturgy. Its logic of sequences is determined by the church tradition, the theological doctrine.

In the general structure of the Liturgy, which is formed as a sequence of four parts (the original internal liturgies), 4 rites, the multifaceted symbolism of the CROSS is fully revealed: crucifixion - death - resurrection (Ascension) - eternal life, which corresponds to the central Christian idea: "Overcome a death by the death".

The first part of the liturgy - the Initial rites (the procession of the Priest to the altar) are accompanied by the Priest's proclamation of the postulate: "In the Name of the Father, and of the Son and of the Holy Spirit", and proclaimed by the congregation "Amen". The Rite of Repentance also ends with the public proclamation of "Amen". It is here, at the end of the Rite of Repentance, that "Kyria" and "Gloria" follow one after another. These 
first two missa's musical sections are within the first part of the liturgical action, i.e. the initial rites, concluding the Rite of Repentance.

The second part - the Liturgy of the Word (the Priest reads a psalm, followed by the singing of "Hallelujah") - appears as a reading from the Holy Gospel. The Priest concludes the reading: "Glory to You, o Lord", everybody: "Glory to You, o Christ". This means that the "Gloria" atmosphere, which first appeared in the musical part within the Rite of Repentance, continues in the second part of the Liturgy. At the end of the second part of the liturgy there is "Credo", the third missa's musical section.

The Liturgy of the Eucharist is the third part of the liturgy (Gift offering; Breaking of The Bread as the Christ's body). The Priest raises bread and wine above the altar, proclaiming: "Blessed are you, O Lord, God of the Universe" - this is a prolonged church action. The fourth missa's musical section is the logical continuation of this part of the Eucharist: "Sanctus Osanna - Benedictus - Osanna". In contrast to the first three missa's musical sections, which are present at the end of the liturgical action's previous stages (respectively, its second and third parts), "Sanctus Benedictus" is present in the center of the third (the Eucharist's) part.

In continuation of the Eucharist (at this stage, the Priest, calling on the Holy Spirit, stretches out his hands over the gifts so that they become the Body and Blood of Christ), after the symbolical conversion of the Priest into Jesus Christ, the liturgical action is approaching its culminating stage - the symbolic generalization of Death and Resurrection. At the end of the Holy Communion rite, after the Priest's words "Greet each other with peace and love", the fifth missa's musical section is introduced - the closing prayer "Agnus Dei". But the third part of the liturgy does not end with the vocal prayer (the Holy Communion rite is continued). Thus, the third part of the church action - the liturgy of the Eucharist - contains two final missa's musical sections - "Sanctus - Benedictus" and "Agnus Dei". There is a certain structural similarity to the liturgy's first part, which also contains two missa's musical sections.

Thus, the five musical sections included in the composer's missa are present within the first three parts of the Liturgy. "Kyria"and "Gloria" take on the meaning of the Lord, glorifying the Heavenly Father after the Rite of Repentance (the 1st part). "Credo" is a logical perpetuation of the Liturgy of the Word (the second part). Two final sections of the composer's missa "Sanctus - Benedictus" and "Agnus Dei" - mark the stages of the Holy Communion rite in the Liturgy of the Eucharist (the third part). Separated from the general liturgical context, the sections of the composer's missa reflect it at the level of a genetic memory. Therefore, it is important to know all the conditions for the musical structures introduction into the liturgical action as a whole, as the matter of the composer's missa exceeds the meaning that is directly expressed in its sections at the level of a verbal-musical unity. 
In the musical sections included in the missa as a composer's genre, there is no contextual component of the liturgy's last and the shortest (the 6th) part associated with the final rites' conduction (the Priest's words: "The Lord is with you". Everybody: "And with your spirit". Afterwards, the Priest proclaims the three Persons of the Holy Trinity - The Lord is the Father, and the Son, and the Holy Spirit). The Priest's words "Ite, Missa est" ("Go in the peace of Christ") addressed to the congregation and the parishioners' response "Deo gratias" are resolved in a dialogic form as two vocal phrases. This missa's musical section completes the liturgy. In this very section the final and key for the whole liturgy musical word "missa" is proclaimed, for which the liturgy is conducted. This piece of music obligatory completes the church missa, never the composer's missa, because the latter cannot perform the church's function of absolution. Consequently, there are 6 sections in the Antiphonary missa and 5 parts in the composer's missa. The difference between the Antiphonary missa and the composer's missa means a change in the numerical symbolism, ordo missa, as well as in the general content, structure and dramatic process.

\section{Invariant-variant nature of the Gregorian missa}

According to the traditional opinion on the medieval Gregorian missa, the canon dominance is obvious. But it is necessary to clarify the content of this general rule, setting the boundaries of the canonical (invariant) in the Gregorian missa, as well as the meanings and possibilities (variant) in its context.

First of all, it is expedient to establish a measure of canonicity in relation to the medieval Gregorian missa general structure.

The six-part ("Kyrie eleison", "Gloria", "Credo", "Sanctus", "Agnus Dei", "Ite, missa est") structure of the medieval Gregorian missa-ordinarium is not the only one possible. In the structure of the Roman Catholic liturgy missa-ordinarium is carried out in two full versions: the first one is complete, covering the entire six-part structure of the missa, and the second one, being reduced, provides for the exclusion of its third part ("Credo"). As a result, the missa becomes a five-part, given the fact that "Ite, missa est" becomes its final part. The equivalent two-variable existence of the Roman Catholic liturgy's musical parts (with "Credo" and without it) reflects the structure of "Liber Usualis Missae et Officii" ". In the Roman Antiphonary's section "Cantus ordinarij Missae" subsection "Kyrie, Gloria, etc." contains eighteen five-part missae, in each of which "Credo" is absent. And only after the presentation of eighteen five-part missae there are presented separately eighteen numbered "Credo", each of which is relevant to a particular missa.

${ }^{4}$ Liber usualis missae et officii, Typis Societatis S. Joannis Evangelistae, Parisiis, Tornaci, Romae, 1953. 
It should be emphasized that both structural variants of the liturgical missa (six-part and five-part) appear as related to the ordinarium, i.e. performed as a part of the liturgy intended for "every day". The conditions for a full sixpart missa-ordinarium in the liturgy performing require a more solemn atmosphere, while the five-part missa-ordinarium provides more everyday circumstances and the possibility of a more concise conducting of the whole liturgy. The two-variant coexistence of the missa-ordinarium as a part of the Roman Catholic liturgy proves the peculiar relevance of the canon doubling, that is, going beyond its unambiguous six-part functional abidance.

Secondly, the variability of the canon interpretation in the canonical Roman Catholic missa's musical parts is evidenced by the fact that with the absolute preservation of the verbal-textual basis in its eighteen versions, each of them is distinguished by the church dedication, that is, the purpose to be performed during a particular church holiday. The purpose of the missa is indicated before each text-musical liturgical-prayer cycle introduced in "Liber Usualis Missae et Officii". It contains information about when, during which church holiday the appropriate prayers should be sung. The following line, which precedes the musical-verbal text, written in the neume notation accompanied by Latin, appears as a clarifying name.

Let us analyze the manifestations of variability in the canon interpretation in the first ten missae "Liber Usualis Missae et Officii".

For example, the purpose of the missa, placed next to number I, testifies that these prayers are intended for worship during the Easter period ("Tempore Paschali"), while its subtitle - "Lux et origo" ("Light and origin") - expresses the main Christian concepts of the Lord's Resurrection in the Roman Catholic theology.

The next missa is numbered II. "In Festis Solemnibus. 1" ("Kyrie fons bonitatis") must be proclaimed in "Triumph holiday", when the Lord appears as a "Source of Good". III missa - "In Festis Solemnibus. 2"("Kyrie Deus sempiterne") appears as a kind of the church holiday's first day continuation, which praises the Lord as "Eternal God". So there appears a kind of "diptych" (large cycle), consisting of two missae, the performance of which is meant for the solemn feasts in the Lord's Glory.

Being part of the next large cycle in "Liber Usualis Missae et Officii" composition, numbers IV, V, VI, VII, VIII are united by a common purpose "In Festis Duplicibus". The hypostasis of the Lord God is embodied in the subheadings of each of the first four of them (from IV to VII); VIII missa "De Angelis" is dedicated to the embodiment of the image of the Lord's messengers.

The third large thematic cycle in the Roman Antiphonary's composition is formed by two missae (numbers IX and X), in which the Virgin Mary is praised ("In Festis B. Mariae Virginis"). Again, different 
subheadings certify the different theological concepts of the image of the Mother of God.

An additional "mark" that indicates the presence of internal large thematic cycles in "Liber Usualis Missae et Officii" composition is the presence of double numbering. Its essence is that along with the Roman numbering, which marks the antiphonary's missae, there are also Arabic numerals that record the missa's number in the relevant internal thematic cycle (for example, IX - "In Festis B. Mariae Virginis. 1"). Such double numbering is inherent in each of the selected antiphonary's internal thematic cycles.

Thus, the variability of the antiphonary's missae matter is manifested in their purpose and meanings concretization in the subheadings.

Thirdly, each of the eighteen antiphonary's missae, retaining a single musical-textual form (according to Kholopova ${ }^{5}$ ) and a common technique of musical composition (cento-writing), has an original melodic nature. Its nature is entirely due to the "program" that has a certain internal thematic cycle in the antiphonary's composition and each missa in its structure.

It is from here that the content's future individualization of the Roman Catholic liturgy's musical part in the composer's missa begins with the difference between the "program" purpose of the antiphonary's missae which has found its expression in various intonation-melodic fillings of the prayer verbal text.

\section{Theological and musical preconditions for the composer's missa genesis}

The Roman Catholic medieval liturgy contains the systemic origins of the religious and the spiritual preconditions regarding the formation of musical semiotics. The Roman liturgy as a sacred integrity, the structure of which includes the missa's musical sections, contains the primary origins of musical semiotics. The transforming principle is at the heart of the composer's missa: musical sections, gaining independence and overcoming disconnection, separated from the general liturgical context. They merged into a musical genre, the performance of which no longer required the presence of a church environment, blending with a sacred action and nonmusical sections. The composer's missa acquired the qualities of a newly created form of integrity, in the dramatic logic of which the musical patterns were built, that in the future would spread to the entire genre system, which would form not only sacred but also secular genres. However, the separation of the composer's missa (as well as the beginning of the composers' era, which replaced the anonymous art era) from the liturgical environment and

\footnotetext{
${ }^{5}$ Kholopova, Valentina, Formy muzykal'nykh proizvedeniy [Forms of Musical Works], Lan', St. Petersburg, 2001.
} 
temple action did not imply an absolute break with its mother's church "womb" - the theological concept. Instead, a supra-genre memory is preserved in the composer's missa - these are connections with the liturgy, the theological concept and temple action.

The long way to separate the composer's missa from the temple action was due to two interacting inherently reformative processes, which took place simultaneously in the late medieval spiritual culture (the 11th - 15th centuries). The change in theological and liturgical consciousness, which took place at the turn of the 12th and the 13th centuries, influenced the art of the development of composition. At that time, according to Peter Bitsilli, "terrible in its inhumanity medieval asceticism" " was transformed by the penetration into the religious consciousness of historicism and individualism, the manifestations of which the scholar associated with the Francis of Assisi's figure and activities (Franciscus Assisiensis, 1181/1182 - 1226). Peter Bitsilli interpreted the time of the Franciscan Order founder's canonization by the Roman Church (1226 - 1228) as "the majestic fact of the Modern history, of our time," when the religious "image of perfection" had been embodied "in a real living personal image"7. Marked by the new Christian individuality's nascence, the turn of the 12th and 13th centuries actualized the gradual transition to the author's work in music, giving it the first signs of independence. Simultaneously with the Francis's older contemporaries, the Notre-Dame school of polyphony founders Léonin (1150 - 1201) and Pérotin (1160 - 1230) laid the basis for the individualized authorial development of musical techniques, and confirmation for new genres. The precondition for this was the musical notation reform ${ }^{8}$, introduced by the Benedictine monk Guido of Arezzo (990 - 1050), as the prime cause of innovations in the field of medieval polyphony of writing.

These mentioned interdependent processes of religious and musical thinking individualization have led to the beginning of the composer's missa prehistory, associated with the name of the French Ars nuova poet and musician Guillaume de Machaut $(1300$ - 1377). Created by the French poet in approximately 1360 on the basis of the ordinarium complete missa "Messa de Nostre Dame" called Reims (intended for performance in the Cathedral of Reims), it appeared as a unique phenomenon in the church and musical history. Guillaume de Machaut's four voices choral score "Messa de Nostre Dame" at the time of its origin was integral to the general liturgical context, acquiring the value of a significant standard of the liturgical supra-

\footnotetext{
${ }^{6}$ Bitsilli, Peter, Mesto Renessansa $v$ istorii kul'tury [Place of the Renaissance in cultural history], MIFRIL, St. Petersburg, 1996, p. 177.

${ }^{7}$ Ibidem, p. 175.

${ }^{8}$ Pospelova Rimma, "Reforma notacii Gvido Aretinskogo: Prolog $k$ Antifonariyu" ["The notation reform of Guido of Arezzo: Prologue to the Antiphonary"], in "Sator tenet opera rotas"/ 2003, Moscow, pp. 48 - 56.
} 
genre memory as the composer's missa feature of the future. The process of the liturgical ordinarium transforming into an artistic phenomenon is connected with Guillaume de Machaut's four voices missa, defined by Nina Gerasimova-Persidskaya as being "innovative". Performed during the liturgy in the Cathedral of Reims, G. de Machaut's missa retained the artistic integrity of the work of art (that is, its sections were not divided by the verbal liturgical "inserts"). In connection with G. de Machaut's missa, the interrelated questions arise regarding "a musical phenomenon as a 'work' formation" 10 , and within these problematic limits - a work of a "large scale", "large composition" "11, according to N. Gerasimova-Persidskaya's definition. On the basis of N. Gerasimova-Persidskaya's concept, we can reach the following conclusion: G. de Machaut's missa has "rec facta" (the finished work of art) features as noted and structured by the author, but despite this it cannot be considered as the embodiment of "Opus-Musik", as it was intended to be performed in the context of the church liturgy. Therefore, the G. de Machaut's missa's historical significance is complemented by its borderline, transitional nature from its function as the liturgy's component to an independent genre phenomenon.

The composer's missa, having become a musical genre whose performance does not require the obligatory belonging to the temple timespace, takes place outside the church action and maintains a genetic connection with the liturgy. The ways of other musical genres (from monumental to miniature) forming come like a kind of "rays" from the composer's missa as a cyclical genre.

\section{Conclusions}

A number of interrelated problems was solved in the study: the missa concept meanings' system unity definition in the context of the Roman Catholic liturgy; the order of the missa's musical sections in the liturgy's structure; theological and musical preconditions for the composer's missa genesis. The result of the study was the liturgical nature of the composer's missa determination as a musical genre and a subject for a musicological analysis.

A measure of canonicity in relation to the medieval Gregorian missaordinarium general structure was established as follows, having in view the next levels: structural; dedicational (intended to be performed during a certain church holiday); internal thematic cycles manifestation; musical solution. The original melodic nature of each missa is due to the "program"

\footnotetext{
${ }^{9}$ Gerasimova-Persidskaya, Nina, Muzyka. Vremya. Prostranstvo [Music. Time. Space], Dukh i litera, Kyiv, 2012, p. 280.

${ }^{10}$ Ibidem, p. 277.

${ }^{11}$ Ibidem, p. 278.
} 
that has a certain internal thematic cycle in the antiphonary's composition. The separation of the composer's missa from the temple action was due to reformative processes in the late medieval spiritual culture. The change in theological and liturgical consciousness influenced the art of composition development. The penetration into the religious consciousness of historicism and individualism is associated with the Francis of Assisi's activities.

The new Christian individuality's nascence has actualized the gradual transition to the author's work in music. The first polyphonic complete missa "Messa de Nostre Dame" has appeared as a unique phenomenon in the church and musical history. The process of the liturgical ordinarium transforming into an artistic phenomenon is connected with Guillaume de Machaut's four voices missa, which retained the artistic integrity of the work of art. G. de Machaut's missa has "rec facta" (the finished work of art) features, but despite this it cannot be considered as the embodiment of "Opus-Musik", as it was intended to be performed in the context of the church liturgy. The composer's missa, having become a musical genre whose performance does not require the obligatory belonging to the temple timespace, maintains a genetic connection with the liturgy. The ways of other musical genres (from monumental to miniature) forming come like a kind of "rays" from the composer's missa as a cyclical genre.

\section{Bibliography:}

Bitsilli, Peter, Mesto Renessansa $v$ istorii kul'tury [Place of the Renaissance in cultural history], MIFRIL, St. Petersburg, 1996.

Gerasimova-Persidskaya, Nina, Muzyka. Vremya. Prostranstvo [Music. Time. Space], Dukh i litera, Kyiv, 2012.

Kholopova, Valentina, Formy muzykal'nykh proizvedeniy [Forms of Musical Works], Lan', St. Petersburg, 2001.

Liber usualis missae et officii, Typis Societatis S. Joannis Evangelistae, Parisiis, Tornaci, Romae, 1953.

Pospelova Rimma,"Reforma notacii Gvido Aretinskogo: Prolog $k$ Antifonariyu" "The notation reform of Guido of Arezzo: Prologue to the Antiphonary"], in "Safot tenet opers rotas" / 2003, Moscow, pp. 48 - 56.

Simakova, Natalia, Vokal'nyye zhanry epokhi Vozrozhdeniya [Renaissance vocal genres], Muzyka, Moscow, 1985, p. 15. 